\title{
Epigenetic regulation of pulmonary arterial hypertension
}

\author{
Xue-Feng $\mathrm{Xu}$, Fen Cheng and Li-Zhong Du
}

Pulmonary arterial hypertension (PAH) is diagnosed as a sustained elevation of pulmonary arterial pressure to more than $25 \mathrm{~mm} \mathrm{Hg}$ at rest or to more than $30 \mathrm{~mm} \mathrm{Hg}$ with exercise. PAH is an intrinsic disease of the pulmonary vascular smooth muscle and endothelial cells in association with plexiform lesions, medial thickening, concentric laminar intimal fibrosis and thrombotic lesions. Pulmonary vascular remodeling is the characteristic pathological change of PAH. The pathogenesis of PAH has been studied at the level of smooth muscle and endothelial cells. Existing research does not adequately explain susceptibility to the disease, and recent evidence reveals that epigenetic alterations may be involved in PAH. Epigenetics refers to all heritable changes in phenotype or in gene expression states, including chromatin remodeling, DNA methylation, histone modification and RNA interference, which are not involved in the DNA sequence itself. This review will focus on recent advances in epigenetics related to $\mathrm{PAH}$, including epigenetic changes of superoxide dismutase, endothelial nitric oxide synthase and the bone morphogenetic protein signaling pathway. This will provide new insight for improved treatment and prevention of PAH. Future work aimed at specific epigenetic treatments may prove to be an effective therapy for patients with PAH. Hypertension Research (2011) 34, 981-986; doi:10.1038/hr.2011.79; published online 16 June 2011

Keywords: epigenetics; pathogenesis; pulmonary arterial hypertension; pulmonary vascular remodeling

\section{INTRODUCTION}

Pulmonary arterial hypertension (PAH) is diagnosed as a sustained elevation of pulmonary arterial pressure to more than $25 \mathrm{~mm} \mathrm{Hg}$ at rest or to more than $30 \mathrm{~mm} \mathrm{Hg}$ with exercise, and both concurrent with a mean pulmonary capillary wedge pressure and left ventricular end-diastolic pressure of less than $15 \mathrm{~mm} \mathrm{Hg} .{ }^{1}$ According to the 4th World Symposium on Pulmonary Hypertension in 2008, PAH includes idiopathic $\mathrm{PAH}$, familial $\mathrm{PAH}$ and acquired $\mathrm{PAH} .^{2}$ The latter arises in association with collagen vascular disease, portal hypertension, infection with the human immunodeficiency virus, drugs and toxins, and other conditions. This category can have significant venous or capillary involvement as a consequence of pulmonary venoocclusive disease and pulmonary capillary hemangiomatosis, as well as persistent pulmonary hypertension of the newborn (PPHN). ${ }^{2}$

The pulmonary circulation is a low-pressure, low-resistance and high-flow system that has a pivotal role in gas exchange and oxygen transport. The pulmonary arteries have thinner muscular media, and the tone of pulmonary vascular smooth muscle is lower than that of most systemic arteries. ${ }^{3}$ The pulmonary vascular wall possesses three layers: an outer adventitia containing fibroblasts, a media composing of smooth muscle cells and one or more elastic laminae, and an intima characterized by a single layer of endothelial cells. Furthermore, within each layer, there are various extracellular matrix components involved in a number of functions. ${ }^{4}$ From a physiological point of view, pulmonary hypertension is also divided into the two broad categories of obliterative pulmonary hypertension and secondary pulmonary hypertension. ${ }^{5}$ Obliterative PAH is an intrinsic disease of the pulmonary vascular smooth muscle and endothelial cells in association with plexiform lesions, medial thickening, concentric laminar intimal fibrosis and thrombotic lesions. The obliterative process impedes blood flow through small pulmonary vessels resulting in chronic and sustained pulmonary hypertension. Those alterations can be seen in idiopathic PAH, familial PAH, acquired PAH and PPHN.

The main change in $\mathrm{PAH}$ is a progressive increase in pulmonary vascular resistance resulting in right ventricular failure and ultimately death. Vasoconstriction, remodeling of the pulmonary vascular wall and thrombosis will contribute to increased pulmonary vascular resistance in PAH. ${ }^{6}$ These findings suggest the presence of an imbalance between vasodilators and vasoconstrictors, growth inhibitors and mitogenic factors, and antithrombotic and prothrombotic determinants. ${ }^{1}$ Pulmonary vascular remodeling (PVR) is the characteristic pathological change of PAH. Unlike large systemic vessel atheromata, remodeling of pulmonary vasculature occurs primarily in small vessels $\left(<500 \mu \mathrm{m}\right.$ diameter). ${ }^{3}$ The process of PVR involves all layers of the vessel wall, including hypertrophy (cell growth) and hyperplasia (proliferation) of vascular cells such as endothelial cells, fibroblasts and smooth muscle cells. A hallmark feature of PVR is abnormal smooth muscle cell proliferation leading to medial thickening, which

The Children's Hospital, Zhejiang University School of Medicine, Hangzhou, PR China Correspondence: Professor L-Z Du, Department of Neonatology, The Children's Hospital, Zhejiang University School of Medicine, Hangzhou 310003, PR China. E-mail: dulizhong@yahoo.com.cn

Received 24 January 2011; revised and accepted 6 April 2011; published online 16 June 2011 
includes the distal extension of smooth muscle into small peripheral, normally non-muscular, pulmonary arteries within the respiratory acinus. ${ }^{6}$ Plexiform lesions or abnormal pulmonary vascular endothelial cell proliferation, the classic pathological finding in $\mathrm{PAH}$, is present in about one in three lung biopsy specimens. ${ }^{7}$ The process may be induced by hypoxia, shear stress, inflammation or response to drugs or toxins on a background of genetic susceptibility. ${ }^{6}$ Pulmonary endothelial cell dysfunction of PAH has been shown to be correlated with decreased production of nitric oxide (NO) and prostacyclin and increased production of endothelin.

Previous studies have demonstrated that superoxide dismutase (SOD), endothelial NO synthase (eNOS) and the bone morphogenetic protein (BMP) signaling pathway are strongly associated with the pathogenesis of PVR in PAH. ${ }^{4,7-9}$ Further studies reveal that epigenetic alterations of these protein pathways are involved in PAH. ${ }^{9-11}$ In this review, we will discuss epigenetic regulation of the proteins in $\mathrm{PAH}$.

\section{EPIGENETICS}

Epigenetics describes all heritable changes in phenotype or in gene expression states that are not involved in the DNA sequence itself. ${ }^{12}$ Chromatin remodeling, DNA methylation, histone modification and RNA interference are the tools of epigenetic regulation. DNA methylation and histone modification are the predominant epigenetic phenomena, which selectively activate or inactivate genes that control cell growth, proliferation and apoptosis. Epigenetic modifications provide a mechanism that allows the stable propagation of gene activity states from one generation of cells to the next. ${ }^{13}$ There is a large body of evidence that epigenetic modifications are involved in the pathological mechanisms of many diseases including cancer, asthma and several hereditary disorders. ${ }^{12,14-16}$

\section{DNA methylation}

DNA methylation is essential for the development of mammals and is involved in regulating many cellular processes, such as embryonic development, transcription, $\mathrm{X}$ chromosome inactivation and genomic imprinting. Many human diseases could be associated with aberrant DNA methylation. ${ }^{17}$ The most striking feature of DNA methylation patterns is the presence of $\mathrm{CpG}$ islands, which are unmethylated CpG-rich regions that possess high relative densities of $\mathrm{CpG}$, and are located at the $5^{\prime}$ ends of many genes. ${ }^{18}$ Approximately $60-90 \%$ of all CpGs in the genome are methylated, whereas unmethylated CpG dinucleotides are mainly clustered in the $\mathrm{CpG}$ islands of the gene promoter region. ${ }^{19}$ Mammalian DNA methyltransferases are mainly classified into maintenance DNA methyltransferase (DNMT1) and de novo methylases (DNMT3a and DNMT3b). Maintenance methylase (DNMT1) is highly active to methylate a hemi-methylated DNA that is methylated in one of the doubled-stranded DNA and unmethylated in the other. DNMT3a and DNMT3b can add a methyl group to unmethylated CpG base pairs, leading to the creation of a new hemimethylated and then fully methylated CpG. ${ }^{19}$ In addition to the catalytic role, DNA methyltransferase enzymes themselves might be involved in establishing the silenced state to repress transcription in collaboration with other proteins such as histone deacetylases (HDACs) in the absence of DNA methylation. ${ }^{20,21}$ The demethylation activity of DNA remains uncertain because of the lack of a specific demethylase. In general, methylation of a promoter CpG island is linked with transcriptional silencing of associated genes. DNA methylation can repress transcription directly by blocking transcriptional activators from binding to cognate DNA sequences, or indirectly through methylated CpG-binding proteins that recognize methylated DNA and recruit co-repressors to silence gene expression. ${ }^{21}$

\section{Histone modification}

Genomic DNA is highly folded and compacted by histone and non-histone proteins in the form of chromatin. The distinct levels of chromatin organization are dependent on the dynamic higher order structuring of nucleosomes. The core particle of a nucleosome consists of a highly conserved octamer of core histone proteins (two each of $\mathrm{H} 2 \mathrm{~A}, \mathrm{H} 2 \mathrm{~B}, \mathrm{H} 3$ and $\mathrm{H} 4$ ), accommodating 147 base pairs of DNA. ${ }^{22}$ Histones are integral and dynamic components of the machinery responsible for gene transcriptional regulation. ${ }^{23}$ Regulation of chromatin structure and transcription is driven by post-translational modification of the core histones. This regulation information can be transmitted from one cell generation to the next. Accumulating evidence suggests that histones are modified primarily in the $\mathrm{N}$-terminal tails of the core histones. ${ }^{24}$ Histone-modifying enzymes introduce a complex array of modifications that alter chromatin activity by creating binding sites for protein domains that recognize specific histone modifications, a process which depends mainly on the type of chemical modification and their location in the octamer. The N-terminal tails on the nucleosome surface are subject to several modifications, including acetylation, methylation, phosphorylation, ubiquitination and adenosine diphosphate ribosylation. ${ }^{25}$ These modifications are reported to affect chromosome function via two distinct mechanisms. ${ }^{26}$ Nearly all modifications alter the electrostatic charge of histones, which could change the structural properties of histones or their binding to the DNA. On the other hand, modifications could create binding surfaces for protein recognition modules, and thus recruit specific functional complexes to their appropriate sites of action. Modifications of the specific histone tails are not just a means of reorganizing nucleosome structure, but provide a rich resource library of epigenetic information that may constitute a code that defines actual or potential transcriptional states. ${ }^{24}$ The combination of different histone modifications appearing on different histones at different times can mediate unique cellular responses, which is also referred to as histone coding. ${ }^{27}$

Histone acetylation is one of the most frequent epigenetic modifications. The main positions for acetylation are lysine (K) 9, K14, $\mathrm{K} 18$ and $\mathrm{K} 23$ on histone $\mathrm{H} 3$, and $\mathrm{K} 5, \mathrm{~K} 8, \mathrm{~K} 12$ and $\mathrm{K} 16$ on histone $\mathrm{H} 4{ }^{24,28}$ There is sufficient evidence to show that increased levels of histone acetylation are highly correlated with increased transcriptional activity, whereas decreased levels of acetylation will lead to repression of gene expression. ${ }^{25,29}$ The acetylation and deacetylation of histones are dynamic processes that depend on the balance between histone acetyltransferases and HDACs. ${ }^{28,30}$ Histone acetyltransferases can transfer the acetyl moiety from acetyl coenzyme A onto the lysine residues of histone proteins, whereas HDACs usually repress transcription..$^{30}$ Unlike histone acetylation, histone methylation possesses a dual role in gene expression and may either activate or repress gene expression, which mainly depends on the sites of methylation. ${ }^{31}$ For example, H3 K9 and $\mathrm{K} 27$ methylations are associated with transcriptional silencing, whereas methylations of $\mathrm{K} 4, \mathrm{~K} 36$ and $\mathrm{K} 79$ of $\mathrm{H} 3$ have been associated with gene activity. 22,31 Histone methylation is relatively stable and an irreversible epigenetic mark, and can interact with DNA methylation participating in chromatin remodeling. ${ }^{32,33}$

\section{PAH AND EPIGENETICS}

\section{Reactive oxygen species (ROS) and SOD}

ROS are biologically important $\mathrm{O}_{2}$ derivatives that have an important role in vascular biology via their oxidation/reduction potential. ${ }^{34} \mathrm{ROS}$ include both free radicals, such as superoxide $\left(\mathrm{O}_{2}{ }^{-}\right)$, hydroxyl, peroxyl and hydroperoxyl radicals, and non-radical species, such as hydrogen peroxide $\left(\mathrm{H}_{2} \mathrm{O}_{2}\right) .{ }^{35}$ All vascular cell types, including endothelial cells, 
smooth muscle cells and adventitial fibroblasts, can generate ROS, mainly via cell membrane associated nicotinamide adenine dinucleotide phosphate oxidase. Mitochondria are also an important source of ROS production in the cardiovascular system under normal conditions. $^{35,36}$ Excessive production of ROS may induce irreversible alterations of proteins, lipids and DNA, leading to tissue damage. ROS are not only toxic consequences of cellular metabolism, but also serve as an important intracellular and intercellular second messenger in regulating a variety of downstream signaling pathways via reactions with protein residues. ${ }^{34,35,37}$ The key ROS molecules involved in cell signaling pathways are superoxide and hydrogen peroxide, which have important roles in signal transduction mediated by growth factor, and induce growth and proliferation of vascular smooth muscle cells in response to endothelin. ${ }^{38-40}$ On the other hand, ROS can regulate cellular levels of endothelin and mediate its secretion through increasing endothelin gene promoter activity. ${ }^{39}$ Superoxide reacts rapidly with NO to form peroxynitrite. Peroxynitrite has been reported to inhibit the activity of purified eNOS protein probably via nitration of critical tyrosine residues. Furthermore, increased levels of superoxide will result in the inhibition of eNOS in endothelial cells (Figure 1). ${ }^{39}$ Evidence is emerging that antioxidant treatment or inhibition of the superoxide-generating enzyme, nicotinamide adenine dinucleotide phosphate oxidase, may decrease viability and induce apoptosis in pulmonary arterial smooth muscle cells, repress vascular remodeling, improve endothelial function and reduce inflammation..$^{34,35,41-44}$ As a non-protein thiol source in mammalian cells, the tripeptide glutathione system has an key role in the maintenance of cellular redox status, and especially important for cellular defense against ROS. ${ }^{45,46}$ Glutathione can directly scavenge free radicals in non-enzymatic reactions, and reduce hydrogen peroxide via a reaction catalyzed by the glutathione peroxidases. ${ }^{46,47}$ Previous studies have revealed that glutathione deficiency are closely associated with ROS production. ${ }^{45,48}$

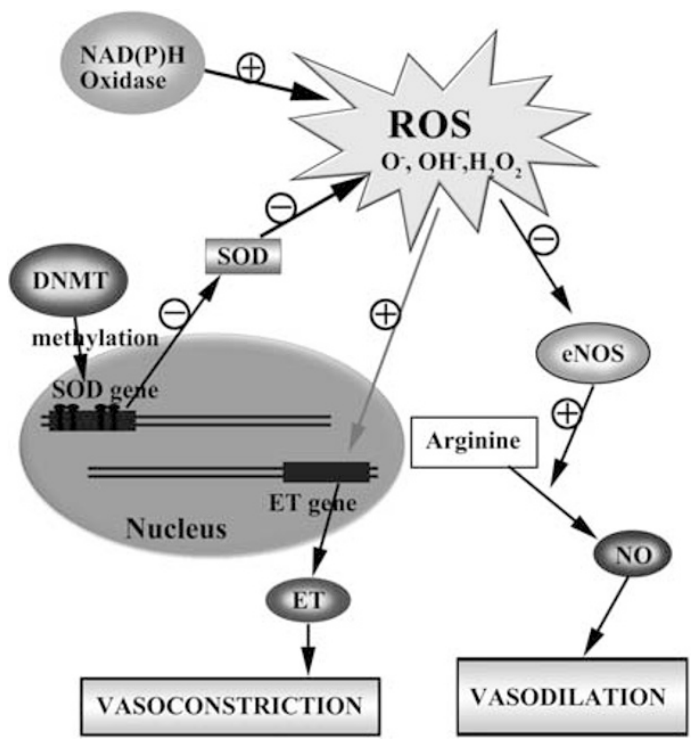

Figure 1 Regulation of vascular tone by ROS signaling pathway in pulmonary artery. DNA methylation of the SOD gene promoter induced by DNMT decreased SOD expression, impeding ROS degradation. The increased ROS production would induce vasoconstriction by the ET and eNOS signaling pathway. DNMT, DNA methyltransferase; eNOS, endothelial nitric oxide synthase; $E T$, endothelin; $N A D(P) H$, nicotinamide adenine dinucleotide phosphate; NO, nitric oxide; ROS, reactive oxygen species; SOD, superoxide dismutase; +, promoted effect; -, inhibited effect.
SOD is one of the main ROS enzymatic scavengers, catalyzing the dismutation of superoxide into $\mathrm{H}_{2} \mathrm{O}_{2}$ and $\mathrm{O}_{2}$, and having an important role in vascular tone, lung function and metabolism of NO. In mammals, there are three isoforms of SOD, CuZn-SOD (SOD1) located primarily in cytoplasm, manganese SOD (SOD2) localized in mitochondria and extracellular SOD (SOD3). ${ }^{49}$ Several lines of evidence indicated that intratracheal administration of recombinant human SOD results in selective dilation of pulmonary circulation blood vessels, reduces pulmonary vascular resistance, significantly improves oxygenation and facilitates the action of inhaled NO in experimental models of PPHN. ${ }^{41,42}$ A study by Kamezaki et al. ${ }^{44}$ revealed that intratracheal gene transfer with adenovirus-mediated SOD suppressed monocrotaline (MCT)-induced pulmonary hypertension in rats, and further indicated that increased oxidative stress in the lung has a crucial role in the pathogenesis of pulmonary hypertension. Another investigation by Archer et al. ${ }^{9}$ described that decreased SOD2 expression in PAH was not associated with the SOD gene mutation, but highly correlated with epigenetic regulation. The SOD2 gene promoter and several of its introns have CpG islands offering potential methylation sites. Using genomic bisulfite sequencing, two discrete sites of differential hypermethylation, one in intron 2 and the other in the promoter, were identified in a fawn-hooded rat (FHR) model of spontaneous and heritable PAH. ${ }^{9}$ The SOD2 gene methylation was found to be seen in the FHR pulmonary artery but not in the FHR aorta. Compared with control, the maintenance DNMT1 and DNMT3b were significantly upregulated in lung tissue and pulmonary arterial smooth muscle cells from FHR. Furthermore, the methyltransferase inhibitor 5-azacytidine may decrease the methylation of an intron 2 sequence. This epigenetic downregulation of SOD2 impairs $\mathrm{H}_{2} \mathrm{O}_{2}$-mediated redox signaling, activates hypoxiainducible factor- $1 \alpha$ and forms a proliferative, apoptosis-resistant state. ${ }^{9}$ In FHR pulmonary arterial smooth muscle cells SOD2 gene therapy, application of the methyltransferase inhibitor 5-azacytidine would result in hypoxia-inducible factor- $1 \alpha$ inactivation. ${ }^{9}$

\section{BMP signaling pathway}

BMPs are signaling molecules that belong to the transforming growth factor- $\beta$ superfamily whose proteins bind to serine/threonine kinase receptors transducing signals. ${ }^{50,51}$ More than 20 BMPs have been identified, and can be synthesized and secreted from a variety of cell types, including pulmonary vascular smooth muscle and endothelial cells, and have an important role in regulating cell differentiation, proliferation and apoptosis. ${ }^{5,52}$ The signaling transduction of BMP-mediated pathways involves two types of transmembrane receptors, BMP receptor I and II (BMPR2). BMPR2 are abundantly located in the pulmonary vascular endothelium, smooth muscle cells and adventitial fibroblasts. ${ }^{53,54}$ Evidence is also emerging that loss of BMPR2 function in smooth muscle, including BMPR2 gene mutation and expression reduction, is sufficient to produce PAH..$^{53,55,56}$ Furthermore, loss of BMPR2 signaling in endothelium could induce the formation of plexiform lesions. ${ }^{53}$ Morrell et al..$^{57}$ found that BMP can inhibit proliferation of smooth muscle cells originating from normal pulmonary arteries, but fails to suppress the proliferation of those from primary pulmonary hypertension.

The inhibitor of differentiation (Id) proteins are one of the most important targets of BMPs and they have a pivotal role in regulating growth and phenotype modulation of vascular smooth muscle cells via their negative interactions with key transcription factors. ${ }^{50}$ Sustained Smad1 activation and Id1 expression mediated by BMP signaling pathways will lead to inhibition of proliferation of vascular cells and to apoptosis, whereas the downregulation of Id1 may 
contribute to vascular remodeling and the development of pulmonary hypertension. ${ }^{10,56}$ The promoter of $I d 1$ gene contains BMP-responsive element, which consists of Smad-binding elements and a GC-rich region. ${ }^{58}$ In addition to hypoxia-inducible factor- $1 \alpha$, HDAC recruitment in the Id 1 promoter is also involved in hypoxia-induced PAH. ${ }^{10}$ Chromatin immunoprecipitation assay using antibody against HDAC revealed that hypoxia may enhance the recruitment of HDAC to the BMP-responsive element region of $I d 1$ gene promoter. HDAC-specific inhibitor trichostatin A could not significantly affect BMP-induced Id1 expression in normoxic cells, but could prevent suppression of Id1 expression by hypoxia. This further indicated that HDAC activity is required for hypoxic regulation of BMP-mediated $I d 1$ gene expression.

\section{PPHN AND ENOS}

PPHN is defined as a failure of pulmonary vascular resistance to fall at birth, resulting in unoxygenated blood to be shunted to the systemic circulation, myocardial dysfunction and severe hypoxemia. ${ }^{8,59}$ PPHN can be primary or secondary to a variety of clinical conditions, including asphyxia, sepsis, pneumonia, meconium aspiration syndrome and antenatal exposure to non-steroidal anti-inflammatory drugs. ${ }^{60}$ Cesarean delivery, late preterm, large for gestation age and maternal asthma might be also important risk factors for PPHN. ${ }^{61}$ Pathophysiological mechanisms of PPHN have been investigated at the level of endothelial as well as smooth muscle function. ${ }^{59}$ Functional changes in PPHN are primarily correlated with endothelial dysfunction, resulting in an imbalance between vasodilation and vasoconstriction. ${ }^{62}$ As a predominant endothelium-derived vasodilator, NO can induce vascular smooth muscle relaxation via activation of smooth muscle soluble guanylate cyclase and cyclic guanosine monophosphate production, following the mobilization of extracellular calcium. ${ }^{59,63}$ Furthermore, NO may downregulate endothelin-1 production. ${ }^{64}$ Inhaled NO therapy has been reported to improve systemic oxygenation in infants with PPHN, and may reduce the need for more invasive treatments, including extracorporeal membrane oxygenation. ${ }^{65-67}$ In vascular endothelial cells, eNOS is responsible for the production of the majority of NO mainly during conversion of $\mathrm{L}$-arginine to L-citrulline. ${ }^{68}$ There is more and more evidence that the levels of eNOS expression are conspicuously associated with PPHN. The decreased eNOS expression might contribute to the development of PPHN. ${ }^{69,70}$ However, chronic hypoxia induced eNOS expression in the rat lung. ${ }^{71}$ Rapid progressive pulmonary hypertension of the newborn led to compensatory induction of eNOS synthesis in the endothelial cells affected by PAH. ${ }^{72}$ In our rat model of PPHN induced by hypoxia and indomethacin, eNOS expression in the endothelial cells is also significantly upregulated. ${ }^{73}$

The eNOS gene is composed of 26 exons spanning approximately $21 \mathrm{~Kb}$ of genomic DNA on chromosome 7q35-36, and its promoter shares many features with other endothelial-specific promoters including Ets, GATA, Sp1 and other cis-regulatory elements that are required for their basal expression. ${ }^{68}$ In normal conditions, eNOS expression is highly restricted to vascular endothelial cells. ${ }^{74,75}$ Furthermore, this endothelial-specific expression of eNOS is regulated by epigenetics. ${ }^{68}$ Chan et al. ${ }^{76}$ revealed that the nine $\mathrm{CpG}$ doublets in the proximal eNOS promoter were completely unmethylated or lightly methylated in human endothelial cells. In contrast, the proximal eNOS promoter was almost completely methylated in all of the vascular smooth muscle cells investigated. Within endothelial cells, the eNOS core promoter is highly enriched in acetylated histone $\mathrm{H} 3 / \mathrm{K} 9$ and $\mathrm{H} 4 / \mathrm{K} 12$, and methylated $\mathrm{H} 3 / \mathrm{K} 4 .{ }^{77}$ Furthermore, HDAC inhibitor trichostatin A may induce eNOS expression in non-endothelial cells, and small RNA may suppress eNOS expression by altering histone acetylation and DNA methylation in endothelial cells. ${ }^{78,79}$

In our rat model for PPHN, the levels of eNOS mRNA and protein expression were significantly upregulated. ${ }^{73}$ To better understand eNOS gene regulation in endothelial cells, we isolated pulmonary vascular endothelial cells via magnetic-activated cell sorting. We found that there was a hypomethylation trend in CpG sites in the rat eNOS core promoter from pulmonary vascular endothelial cells of PPHN, but there was no statistically significant difference compared with control. In PPHN, the CPG methylation rate at site -98 was higher than that of control, but there was also no statistically significant difference. ${ }^{11}$ However, the abundance of acetylated $\mathrm{H} 3$ and $\mathrm{H} 4$ in the core promoter region of eNOS in PPHN was significantly increased relative to those from the control. On the contrary, acetylation levels of

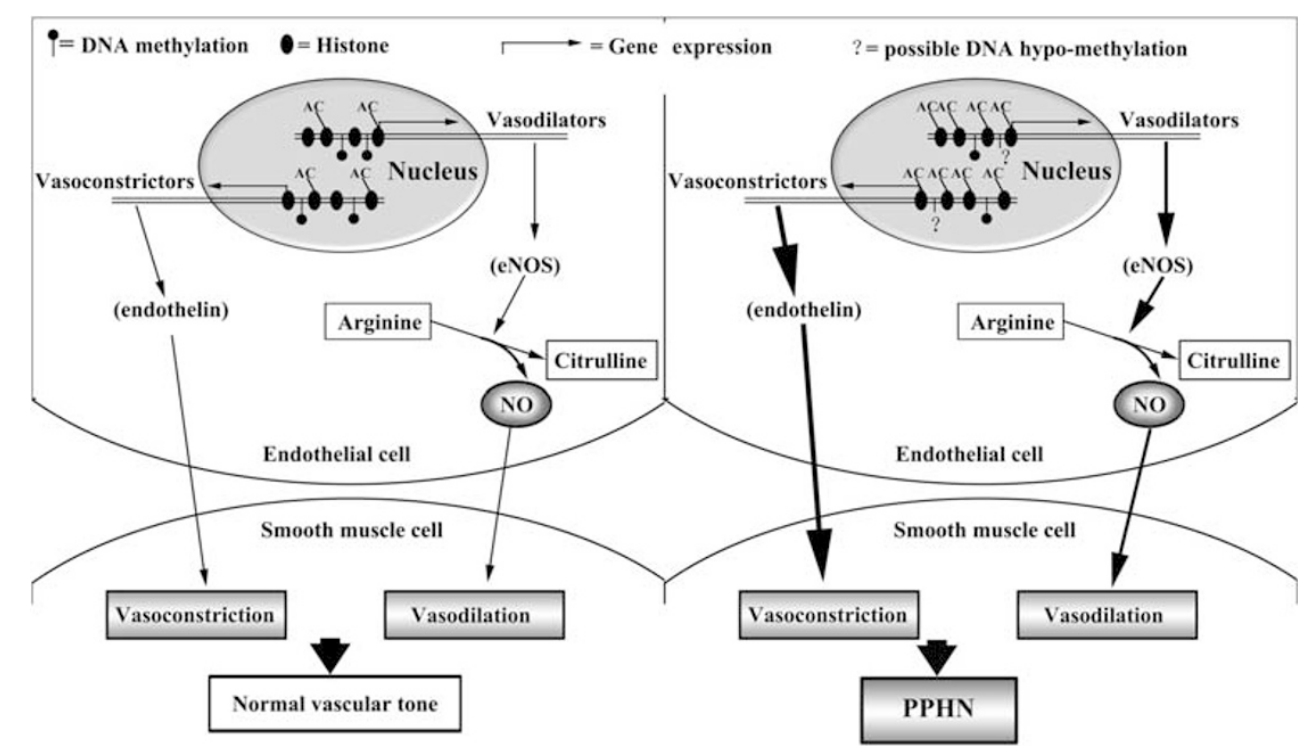

Figure 2 Regulation of the eNOS and endothelin signaling pathways in pulmonary vascular tone. Increased histone acetylation in the eNOS gene promoter might induce eNOS protein expression. However, the increased eNOS expression did not completely offset the effect of vasoconstrictors, resulting in the development of PPHN. AC, acetylation; eNOS, endothelial nitric oxide synthase; NO, nitric oxide; PPHN, persistent pulmonary hypertension of the newborn. 
histones in those promoter regions away from the transcription start sites were relatively lower, even though there was no significant difference. ${ }^{11}$ These alterations of epigenetic modifications at the eNOS promoter were consistent with increased levels of eNOS mRNA and protein in PPHN. The increased eNOS expression might have a protective role in PPHN. However, the increased eNOS expression did not completely offset the effect of vasoconstrictors (such as endothelin), and subsequently leading to PPHN (Figure 2). ${ }^{11}$ The epigenetic differences at the eNOS gene between $\mathrm{PPHN}$ and control suggest that epigenetic processes might, at least in part, be responsible for the pathogenesis of PPHN. This phenomenon, whether or not the epigenetic alterations of the eNOS gene in PPHN could be maintained throughout the life, may be worthy of further investigation.

\section{FUTURE PERSPECTIVES}

Although available literature about epigenetic investigation of PAH is limited, there is evidence that epigenetic mechanisms could be involved in the development of PAH. Given the complex and multifactorial nature of $\mathrm{PAH}$, it seems likely that epigenetic events could influence the establishment or progression of PAH. Further elucidation of the role of epigenetics in PAH is not only conducive to understanding the pathogenesis of $\mathrm{PAH}$ but also to potentially reversing the disease phenotype of the pulmonary vascular structural cells involved in disease pathophysiology. As epigenetic mechanisms for human disease have been identified, some epigenetic therapies are being developed or rediscovered. ${ }^{12,15,80,81}$ Several drugs have been used to intervene in the epigenetic processes leading to the development of cancer. DNA methyltransferase inhibitor decitabine, HDAC inhibitor depsipeptide and suberoylanilide hydroxamic acid have shown promise in clinical trials. ${ }^{82-85}$ However, there are some potential disadvantages in current epigenetic treatments. The lack of specificity for treatment is an important issue. For example, the increased global DNA demethylation via the use of non-selective agents can contribute to increased chromosomal instability. ${ }^{86,87}$ Furthermore, epigenetic effects of the treatment might also have the possibility of being transmitted between generations. ${ }^{80}$

Considering the central role of epigenetics in phenotypic variation in health and disease, it is likely that understanding and manipulating the epigenome holds enormous promise for preventing and treating common human diseases; promise that will provide new insight for improved treatment and the prevention of PAH. Therefore, systematic and extensive epigenetic investigations should further focus on $\mathrm{PAH}$. Moreover, some specific anti-epigenetic agents aimed to the certain genes associated with human diseases are worth further investigation.

\section{ACKNOWLEDGEMENTS}

We thank Matthew Stevenson for reviewing this manuscript. This work was supported by grants from the National Natural Science Foundation of China (No. 30711120575 and 81070512).

1 Farber HW, Loscalzo J. Pulmonary arterial hypertension. N Engl J Med 2004; 351: 1655-1665.

2 Rabinovitch M. Molecular pathogenesis of pulmonary arterial hypertension. J Clin Invest 2008; 118: 2372-2379.

3 Martin KB, Klinger JR, Rounds SI. Pulmonary arterial hypertension: new insights and new hope. Respirology 2006; 11: 6-17.

4 Jeffery TK, Morrell NW. Molecular and cellular basis of pulmonary vascular remodeling in pulmonary hypertension. Prog Cardiovasc Dis 2002; 45: 173-202.

5 Mandegar M, Fung YC, Huang W, Remillard CV, Rubin LJ, Yuan JX. Cellular and molecular mechanisms of pulmonary vascular remodeling: role in the development of pulmonary hypertension. Microvasc Res 2004; 68: 75-103.
6 Humbert M, Montani D, Perros F, Dorfmuller P, Adnot S, Eddahibi S. Endothelial cell dysfunction and cross talk between endothelium and smooth muscle cells in pulmonary arterial hypertension. Vascul Pharmacol 2008; 49: 113-118.

7 Runo JR, Loyd JE. Primary pulmonary hypertension. Lancet 2003; 361: 1533-1544.

8 Therese P. Persistent pulmonary hypertension of the newborn. Paediatr Respir Rev 2006; 7(Suppl 1): S175-S176.

9 Archer SL, Marsboom G, Kim GH, Zhang HJ, Toth PT, Svensson EC, Dyck JRB, Gomberg-Maitland M, Thebaud B, Husain AN, Cipriani N, Rehman J. Epigenetic attenuation of mitochondrial superoxide dismutase 2 in pulmonary arterial hypertension: a basis for excessive cell proliferation and a new therapeutic target. Circulation 2010; 121: 2661-2671.

$10 \mathrm{Wu} X \mathrm{X}$, Chang MS, Mitsialis SA, Kourembanas S. Hypoxia regulates bone morphogenetic protein signaling through C-terminal-binding protein 1. Circ Res 2006; 99: 240-247.

11 Xu XF, Ma XL, Shen Z, Wu XL, Cheng F, Du LZ. Epigenetic regulation of the endothelial nitric oxide synthase gene in persistent pulmonary hypertension of the newborn rat. J Hypertens 2010; 28: 2227-2235.

12 Adcock IM, Tsaprouni L, Bhavsar P, Ito K. Epigenetic regulation of airway inflammation. Curr Opin Immunol 2007; 19: 694-700.

13 Xu XF, Du LZ. Epigenetics in neonatal diseases. Chin Med J 2010; 123: 2948-2954.

14 Bousquet J, Jacot W, Yssel H, Vignola AM, Humbert M. Epigenetic inheritance of fetal genes in allergic asthma. Allergy 2004; 59: 138-147.

15 Feinberg AP. Phenotypic plasticity and the epigenetics of human disease. Nature 2007; 447: 433-440.

16 Reik W. Stability and flexibility of epigenetic gene regulation in mammalian development. Nature 2007; 447: 425-432.

17 Robertson KD. DNA methylation and human disease. Nat Rev Genet 2005; 6: 597-610.

18 Bird A. DNA methylation patterns and epigenetic memory. Genes Devel 2002; 16 : 6-21.

19 Nakao M. Epigenetics: interaction of DNA methylation and chromatin. Gene 2001; 278: 25-31.

20 Klose RJ, Bird AP. Genomic DNA methylation: the mark and its mediators. Trends Biochem Sci 2006; 31: 89-97.

21 Jones PA, Takai D. The role of DNA methylation in mammalian epigenetics. Science 2001; 293: 1068-1070.

22 Sims III RJ, Nishioka K, Reinberg D. Histone lysine methylation: a signature for chromatin function. Trends Genet 2003; 19: 629-639.

23 Strahl BD, Allis CD. The language of covalent histone modifications. Nature 2000; 403: 41-45.

24 Turner BM. Cellular memory and the histone code. Cell 2002; 111: 285-291.

25 Spencer VA, Davie JR. Role of covalent modifications of histones in regulating gene expression. Gene 1999; 240: 1-12.

26 lizuka M, Smith MM. Functional consequences of histone modifications. Curr Opin in Genet Devel 2003; 13: 154-160.

27 Gilmore JM, Washburn MP. Deciphering the combinatorial histone code. Nat Methods 2007; 4: 480-481.

28 de Ruijter AJ, van Gennip AH, Caron HN, Kemp S, van Kuilenburg AB. Histone deacetylases (HDACs): characterization of the classical HDAC family. Biochem J 2003; 370: 737-749.

29 lizuka M, Smith MM. Functional consequences of histone modifications. Curr Opin Genet Dev 2003; 13: 154-160.

30 Grant PA, Berger SL. Histone acetyltransferase complexes. Semin Cell Devel Biol 1999; 10: 169-177.

31 Martin C, Zhang Y. The diverse functions of histone lysine methylation. Nat Rev 2005; 6: 838-849.

32 Tamaru H, Selker EU. A histone H3 methyltransferase controls DNA methylation in Neurospora crassa. Nature 2001; 414: 277-283.

33 Henckel A, Nakabayashi K, Sanz LA, Feil R, Hata K, Arnaud P. Histone methylation is mechanistically linked to DNA methylation at imprinting control regions in mammals. Hum Mol Genet 2009; 18: 3375-3383.

34 Touyz RM, Schiffrin EL. Reactive oxygen species in vascular biology: implications in hypertension. Histochem Cell Biol 2004; 122: 339-352.

35 Perez-Vizcaino F, Cogolludo A, Moreno L. Reactive oxygen species signaling in pulmonary vascular smooth muscle. Respir Physiol Neurobiol 2010; 174: 212-220.

36 Fike CD, Slaughter JC, Kaplowitz MR, Zhang Y, Aschner JL. Reactive oxygen species from NADPH oxidase contribute to altered pulmonary vascular responses in piglets with chronic hypoxia-induced pulmonary hypertension. Am J Physiol Lung Cell Mol Physiol 2008; 295: L881-L888.

37 Clempus RE, Griendling KK. Reactive oxygen species signaling in vascular smooth muscle cells. Cardiovasc Res 2006; 71: 216-225.

38 Sturrock A, Cahill B, Norman K, Huecksteadt TP, Hill K, Sanders K, Karwande SV, Stringham JC, Bull DA, Gleich M, Kennedy TP, Hoidal JR. Transforming growth factor-betal induces Nox4 NAD(P)H oxidase and reactive oxygen species-dependent proliferation in human pulmonary artery smooth muscle cells. Am J Physiol Lung Cell Mol Physiol 2006; 290: L661-L673.

39 Wedgwood S, Black SM. Role of reactive oxygen species in vascular remodeling associated with pulmonary hypertension. Antioxid Redox Signal 2003; 5: 759-769.

40 Wedgwood S, Dettman RW, Black SM. ET-1 stimulates pulmonary arterial smooth muscle cell proliferation via induction of reactive oxygen species. Am J Physiol Lung Cell Mol Physiol 2001; 281: L1058-L1067. 
41 Steinhorn RH, Albert G, Swartz DD, Russell JA, Levine CR, Davis JM. Recombinant human superoxide dismutase enhances the effect of inhaled nitric oxide in persistent pulmonary hypertension. Am J Respir Crit Care Med 2001; 164: 834-839.

42 Lakshminrusimha S, Russell JA, Wedgwood S, Gugino SF, Kazzaz JA, Davis JM, Steinhorn RH. Superoxide dismutase improves oxygenation and reduces oxidation in neonatal pulmonary hypertension. Am J Respir Crit Care Med 2006; 174: 1370-1377.

43 Wedgwood S, Black SM. Induction of apoptosis in fetal pulmonary arterial smooth muscle cells by a combined superoxide dismutase/catalase mimetic. Am J Physiol Lung Cell Mol Physiol 2003; 285: L305-L312.

44 Kamezaki F, Tasaki H, Yamashita K, Tsutsui M, Koide S, Nakata S, Tanimoto A, Okazaki M, Sasaguri Y, Adachi T, Otsuji Y. Gene transfer of extracellular superoxide dismutase ameliorates pulmonary hypertension in rats. Am J Respir Crit Care Med 2008; 177: 219-226.

45 Leopold JA, Loscalzo J. Oxidative enzymopathies and vascular disease. Arterioscler Thromb Vasc Biol 2005; 25: 1332-1340.

46 Banerjee AK, Mandal A, Chanda D, Chakraborti S. Oxidant, antioxidant and physical exercise. Mol Cell Biochem 2003; 253: 307-312.

47 Dringen R, Gutterer JM, Hirrlinger J. Glutathione metabolism in brain metabolic interaction between astrocytes and neurons in the defense against reactive oxygen species. Eur J Biochem 2000; 267: 4912-4916.

48 Armstrong JS, Steinauer KK, Hornung B, Irish JM, Lecane P, Birrell GW, Peehl DM, Knox SJ. Role of glutathione depletion and reactive oxygen species generation in apoptotic signaling in a human B lymphoma cell line. Cell Death Differ 2002; 9: 252-263.

49 Faraci FM, Didion SP. Vascular protection: superoxide dismutase isoforms in the vessel wall. Arterioscler Thromb Vasc Biol 2004; 24: 1367-1373.

50 Miyazono K, Maeda S, Imamura T. BMP receptor signaling: transcriptional targets, regulation of signals, and signaling cross-talk. Cytokine Growth Factor Rev 2005; 16: 251-263.

51 De Caestecker M, Meyrick B. Bone morphogenetic proteins, genetics and the pathophysiology of primary pulmonary hypertension. Respir Res 2001; 2: 193-197.

52 Zhang S, Fantozzi I, Tigno DD, Yi ES, Platoshyn O, Thistlethwaite PA, Kriett JM, Yung G, Rubin LJ, Yuan JX. Bone morphogenetic proteins induce apoptosis in human pulmonary vascular smooth muscle cells. Am J Physiol Lung Cell Mol Physiol 2003, 285: L740-L754.

53 West J, Fagan K, Steudel W, Fouty B, Lane K, Harral J, Hoedt-Miller M, Tada Y, Ozimek J, Tuder R, Rodman DM. Pulmonary hypertension in transgenic mice expressing a dominant-negative BMPRII gene in smooth muscle. Circ Res 2004; 94 1109-1114.

54 Takahashi H, Goto N, Kojima Y, Tsuda Y, Morio Y, Muramatsu M, Fukuchi Y. Downregulation of type II bone morphogenetic protein receptor in hypoxic pulmonary hypertension. Am J Physiol Lung Cell Mol Physiol 2006; 290: L450-L458.

55 Atkinson C, Stewart S, Upton PD, Machado R, Thomson JR, Trembath RC, Morrell NW. Primary pulmonary hypertension is associated with reduced pulmonary vascular expression of type II bone morphogenetic protein receptor. Circulation 2002; 105 : 1672-1678.

56 Yu PB, Deng DY, Beppu H, Hong CC, Lai C, Hoyng SA, Kawai N, Bloch KD. Bone morphogenetic protein (BMP) type $\|$ receptor is required for BMP-mediated growth arrest and differentiation in pulmonary artery smooth muscle cells. J Biol Chem 2008; 283: 3877-3888

57 Morrell NW, Yang X, Upton PD, Jourdan KB, Morgan N, Sheares KK, Trembath RC. Altered growth responses of pulmonary artery smooth muscle cells from patients with primary pulmonary hypertension to transforming growth factor-beta(1) and bone morphogenetic proteins. Circulation 2001; 104: 790-795.

58 Korchynskyi 0 , ten Dijke P. Identification and functional characterization of distinct critically important bone morphogenetic protein-specific response elements in the Id 1 promoter. J Biol Chem 2002; 277: 4883-4891.

59 Dakshinamurti S. Pathophysiologic mechanisms of persistent pulmonary hypertension of the newborn. Pediatr Pulmonol 2005; 39: 492-503.

60 Rao S, Bartle D, Patole S. Current and future therapeutic options for persistent pulmonary hypertension in the newborn. Expert Rev Cardiovasc Ther 2010; 8: 845-862.

61 Hernandez-Diaz S, Van Marter LJ, Werler MM, Louik C, Mitchell AA. Risk factors for persistent pulmonary hypertension of the newborn. Pediatrics 2007; 120: e272-e282.

62 Hoehn T. Therapy of pulmonary hypertension in neonates and infants. Pharmacol Ther 2007; 114: 318-326.

63 Budhiraja R, Tuder RM, Hassoun PM. Endothelial dysfunction in pulmonary hypertension. Circulation 2004; 109: 159-165.

64 Smith AP, Demoncheaux EA, Higenbottam TW. Nitric oxide gas decreases endothelin-1 mRNA in cultured pulmonary artery endothelial cells. Nitric Oxide 2002; 6: 153-159.

65 Davidson D, Barefield ES, Kattwinkel J, Dudell G, Damask M, Straube R, Rhines J, Chang CT. Inhaled nitric oxide for the early treatment of persistent pulmonary hypertension of the term newborn: a randomized, double-masked, placebo-controlled, dose-response, multicenter study. The I-NO/PPHN Study Group. Pediatrics 1998; 101: 325-334.

66 Clark RH, Kueser TJ, Walker MW, Southgate WM, Huckaby JL, Perez JA, Roy BJ, Keszler M, Kinsella JP. Low-dose nitric oxide therapy for persistent pulmonary hypertension of the newborn. Clinical Inhaled Nitric Oxide Research Group. N Engl J Med 2000; 342: 469-474.

67 Roberts Jr JD, Fineman JR, Morin III FC, Shaul PW, Rimar S, Schreiber MD, Polin RA, Zwass MS, Zayek MM, Gross I, Heymann MA, Zapol WM. Inhaled nitric oxide and persistent pulmonary hypertension of the newborn. The Inhaled Nitric Oxide Study Group. N Engl J Med 1997; 336: 605-610.

68 Fish JE, Marsden PA. Endothelial nitric oxide synthase: insight into cell-specific gene regulation in the vascular endothelium. Cell Mol Life Sci 2006; 63: 144-162.

69 Shaul PW, Yuhanna IS, German Z, Chen Z, Steinhorn RH, Morin FC. Pulmonary endothelial NO synthase gene expression is decreased in fetal lambs with pulmonary hypertension. Am J Physiol-Lung C 1997; 16: L1005-L1012.

70 Villamor E, LeCras TD, Horan MP, Halbower AC, Tuder RM, Abman SH. Chronic intrauterine pulmonary hypertension impairs endothelial nitric oxide synthase in the ovine fetus. Am J Physiol-Lung C 1997; 16: L1013-L1020.

71 Le Cras TD, Tyler RC, Horan MP, Morris KG, Tuder RM, McMurtry IF, Johns RA, Abman $\mathrm{SH}$. Effects of chronic hypoxia and altered hemodynamics on endothelial nitric oxide synthase expression in the adult rat lung. J Clin Invest 1998; 101: 795-801.

72 Hoehn T, Preston AA, McPhaden AR, Stiller B, Vogel M, Buhrer C, Wadsworth RM. Endothelial nitric oxide synthase (NOS) is upregulated in rapid progressive pulmonary hypertension of the newborn. Intens Care Med 2003; 29: 1757-1762.

$73 \mathrm{Xu} \mathrm{XF,} \mathrm{Gu} \mathrm{WZ,} \mathrm{Wu} \mathrm{XL,} \mathrm{Li} \mathrm{RY,} \mathrm{Du} \mathrm{LZ.} \mathrm{Fetal} \mathrm{pulmonary} \mathrm{vascular} \mathrm{remodeling} \mathrm{in} \mathrm{a} \mathrm{rat}$ model induced by hypoxia and indomethacin. J Matern Fetal Neonatal Med 2011; 24: $172-182$.

74 Tai SC, Robb GB, Marsden PA. Endothelial nitric oxide synthase: a new paradigm for gene regulation in the injured blood vessel. Arterioscl Throm Vas 2004; 24: 405-412.

75 Searles $C D$. Transcriptional and posttranscriptional regulation of endothelial nitric oxide synthase expression. Am J Physiol-Cell Ph 2006; 291: C803-C816.

76 Chan Y, Fish JE, D'Abreo C, Lin S, Robb GB, Teichert AM, Karantzoulis-Fegaras F, Keightley A, Steer BM, Marsden PA. The cell-specific expression of endothelial nitric-oxide synthase: a role for DNA methylation. J Biol Chem 2004; 279: 35087-35100.

77 Fish JE, Matouk CC, Rachlis A, Lin S, Tai SC, D'Abreo C, Marsden PA. The expression of endothelial nitric-oxide synthase is controlled by a cell-specific histone code. J Biol Chem 2005; 280: 24824-24838.

78 Gan Y, Shen YH, Wang J, Wang X, Utama B, Wang J, Wang XL. Role of histone deacetylation in cell-specific expression of endothelial nitric-oxide synthase. J Biol Chem 2005; 280: 16467-16475.

79 Zhang MX, Zhang C, Shen YH, Wang J, Li XN, Chen L, Zhang Y, Coselli JS, Wang XL. Effect of 27nt small RNA on endothelial nitric-oxide synthase expression. Mol Biol Cell 2008; 19: 3997-4005.

80 Handel AE, Ebers GC, Ramagopalan SV. Epigenetics: molecular mechanisms and implications for disease. Trends Mol Med 2010; 16: 7-16.

81 Durham A, Chou PC, Kirkham P, Adcock IM. Epigenetics in asthma and other inflammatory lung diseases. Epigenomics-UK 2010; 2: 523-537.

82 Wijermans P, Lubbert M, Verhoef G, Bosly A, Ravoet C, Andre M, Ferrant A. Low-dose 5-aza-2'-deoxycytidine, a DNA hypomethylating agent, for the treatment of high-risk myelodysplastic syndrome: a multicenter phase II study in elderly patients. J Clin Oncol 2000; 18: 956-962.

83 Kantariian H, Issa JP, Rosenfeld CS, Bennett JM, Albitar M, DiPersio J, Klimek V, Slack J, de Castro C, Ravandi F, Helmer III R, Shen L, Nimer SD, Leavitt R, Raza A, Saba H. Decitabine improves patient outcomes in myelodysplastic syndromes: results of a phase III randomized study. Cancer 2006; 106: 1794-1803.

84 Byrd JC, Marcucci G, Parthun MR, Xiao JJ, Klisovic RB, Moran M, Lin TS, Liu S, Sklenar AR, Davis ME, Lucas DM, Fischer B, Shank R, Tejaswi SL, Binkley P, Wright J, Chan KK, Grever MR. A phase 1 and pharmacodynamic study of depsipeptide (FK228) in chronic lymphocytic leukemia and acute myeloid leukemia. Blood 2005; 105 : 959-967.

85 Duvic M, Talpur R, Ni X, Zhang C, Hazarika P, Kelly C, Chiao JH, Reilly JF, Ricker JL, Richon VM, Frankel SR. Phase 2 trial of oral vorinostat (suberoylanilide hydroxamic acid, SAHA) for refractory cutaneous T-cell lymphoma (CTCL). Blood 2007; 109: 31-39.

86 Yang AS, Estecio MR, Garcia-Manero G, Kantarjian HM, Issa JP. Comment on 'chromosomal instability and tumors promoted by DNA hypomethylation' and 'induction of tumors in nice by genomic hypomethylation'. Science 2003; 302: 1153; author reply 1153 .

87 Eden A, Gaudet F, Waghmare A, Jaenisch R. Chromosomal instability and tumors promoted by DNA hypomethylation. Science 2003; 300: 455. 